\title{
Contagion in the Brazilian Interbank Currency Exchange Market: An Empirical Analysis ${ }^{\star}$
}

\author{
- MARIA TANNURI-PIANTO*
}

\begin{abstract}
RESUMO
O risco de contágio é a possibilidade de que a falência de uma instituição financeira afetada por algum choque exógeno gere a falência de outras instituições não afetadas pelo choque inicialmente. Como salienta Upper e Worms (2002) e outros, o efeito dominó no sistema de pagamentos depende do padrão das interligações bancárias. Este artigo estuda a ocorrência de contágio financeiro após a falência exógena de uma instituição autorizada a operar no mercado interbancário de câmbio no Brasil. Os dados contêm informações sobre todas as transações efetivamente realizadas no período 01/08/2000 a 3I/I0/2002. A metodologia adotada mostra a ocorrência da propagação do contágio após várias rodadas subseqüentes à falência inicial. $O$ artigo quantifica o número de instituições que quebrariam e as perdas financeiras do mercado. Existe um aumento substancial no número de falências durante o período pré-eleitoral em 2002.
\end{abstract}

\section{PALAVRAS-CHAVE}

contágio, risco sistêmico, mercado interbancário câmbio, Brasil

\begin{abstract}
The risk of contagion is the possibility that the failure of a financial institution affected by an exogenous shock generates the failure of other institutions not initially affected by the shock. As pointed out by Upper and Worms (2002) and others, the domino effect in the payment system depends on the precise pattern of interbank linkages. This paper studies the occurrence of financial contagion after the exogenous failure of an institution authorized to operate in the Brazilian interbank currency market. The data contain information about all the actual transactions that occurred in this market from August Ist, 2000 to October 3 Ist, 2002. The adopted methodology shows the occurrence of contagion propagation in several subsequent rounds after the initial failure. We quantify the number of institutions that breakdown and the financial losses of the market. There is a large increase in the number of failed institutions during the period of the presidential elections in 2002.
\end{abstract}

KEY WORDS

contagion, systemic risk, interbank currency market, Brazil

\author{
JEL CLASSIFICATION \\ G2I, G28
}

+ This paper is based on the dissertation of Cesar de Oliveira Frade, defended as a requirement for the academic master's program of the Department of Economics - UnB. I would like to thank Maurício Bugarin and Marcos Torres for their valuable suggestions; Antônio da Cunha Filho, José Maria de Carvalho, Geraldo Siqueira and Aílton dos Santos, all from the Central Bank of Brazil, for making the data accessible; and a special thanks to Érica Domingos Silva for her support with the calculations. The usual disclaimer applies.

* Professor of Economics, University of Brasília, Campus Universitário Darcy Ribeiro, ICC norte, Caixa Postal 4302, Brasília-DF, CEP: 70910-900 Brazil. E-mail: tannuri@unb.br.

(Recebido em julho de 2003. Aceito para publicação em julho de 2005). 


\section{INTRODUCTION}

Systemic risk can be generated either by contagion, in the payment system, or by runs on banks, in the banking sector. In the payment system, systemic risk refers to the impact that an insolvent bank can have on the banking system. It may cause other banks to file for bankruptcy depending on their transactions with the insolvent bank. In the banking sector, bank runs usually happen as a response to uncertainty about the liquidity of the banks. The first formalized model about bank runs (Diamond and Dybvig, 1983) proposed contracts to prevent them. This analysis was extended by Jacklin and Bhattacharya (1988), who differentiate the runs caused by panic and those associated with information. In recent years, several models of bank contagion have been developed, among them Rochet and Tirole (1996), Flannery (1996), Huang and Xu (2000), Allen and Gale (2000) and Peñaloza (2002).

In Brazil, concern about the risk of contagion in the payment system motivated the reformulation of the Brazilian Payment System (SPB), on April 22, 2002. It increased the number of Clearing Houses with the purpose of stratifying the operations and reducing systemic risk. We will focus our analysis on the currency exchange transactions that are supervised by one of the Clearing Houses (BMF-Cámbio). The new system reduced risk, by generating guarantees and adopting the payment versus payment (PVP) protocol, but it also elevated the costs of operations. It is important to note that transactions are not required to be realized within the Clearing House and that only $40 \%$ of them were in July 2002. The transactions within the BMF-CAmbio are only susceptible to a controlled and quite small risk. Therefore, we will only consider the transactions realized outside of the Clearing House.

Our data is unique. ${ }^{1}$ Instead of relying on estimates of the bilateral exposures we work with the actual transactions of all Brazilian banks authorized to operate in the exchange market. We collected daily data from August $1^{\text {st }}, 2000$ to October $31^{\text {st }}, 2002$ on all buying and selling contracts in foreign currency realized by all the institutions authorized to operate in this market. We also have daily data on the portfolios of federal public bonds held by these institutions during the same period.

The purpose of this paper is to empirically calculate the dimension of the contagion effect in the interbank currency exchange market in Brazil. This is accomplished by counting the number of banks that breakdown as a consequence of an initial exogenous failure. We also estimate how much the Brazilian Central Bank would spend if it decided to save the bankrupt banks. The largest number of bankruptcies (banks affected by the contagion effect) occurred during the period of the presidential elec-

1 The data was made available by the Department of Foreign Capital and Exchange of the Central Bank of Brazil. 
tions, when a little more than half of the transactions were realized outside of the Clearing House.

The paper is organized as follows. Section 1 presents the background. Section 2 discusses the data and the methodology. Section 3 shows the results and last section concludes.

\section{BACKGROUND}

Both applied and theoretical research in economics has shown that the "domino effect" in the payment system depends on the pattern of the interbank linkages. Allen and Gale (2000) develop a model based on Diamond and Dybvig (1983), which divides the banks in regions, not necessarily geographical, and show that in a market with complete structure (a high level of connections, see Figure 1) there is no contagion effect. On the other hand, in a market with incomplete structure (see Figure 2) there exists a contagion effect.

FIGURE 1 - COMPLETE MARKET STRUCTURE

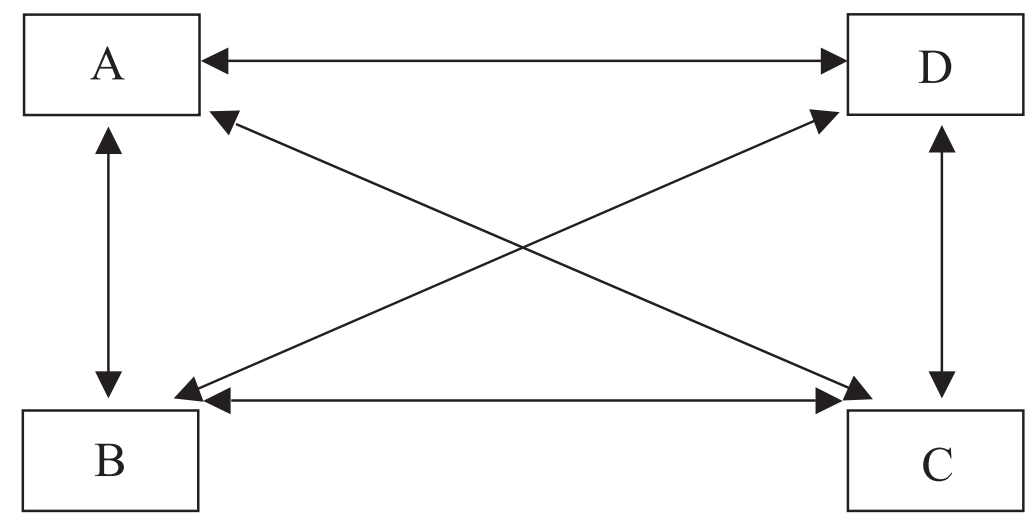

Most articles that estimate the risk of contagion in interbank markets do not use the actual structure of bilateral exposures in these markets, since this data is typically not publicly available. One exception is Furfine (1999), who uses settlement data on bank liquidations to compute bilateral exposures in the U.S. interbank federal funds market. 


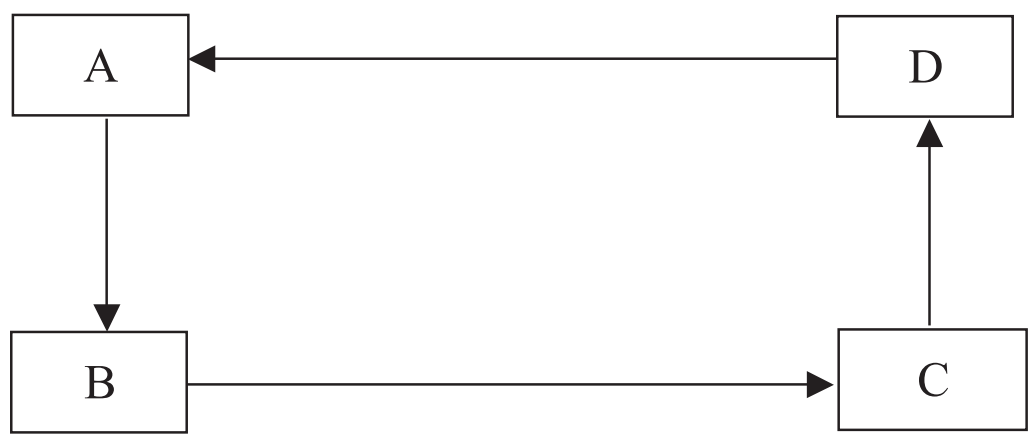

Sheldon and Maurer (1998) estimate the contagion effect in Switzerland using a matrix of interbank loans between 1987 and 1995. They do not consider the derivative markets or currency data. Their results show that the risk of contagion in the Swiss bank system is small and it may occur only if one of the four largest banks in Switzerland breakdown. In this case the effects are very severe and only a few banks would survive these shocks.

Upper and Worms (2002) make use of bank balance sheet data to estimate a matrix of bilateral credit relationships. They consider more than 3000 German banks in December 1998, classified into maturity categories. They cannot observe the actual bilateral exposures, but they estimate them based on the sum of each bank's interbank loans and deposits and a hypothesis of independence. Under these assumptions, if a bank is both lender and borrower its element on the main diagonal of the matrix is non-zero (implying that the bank was a lender to itself). Therefore, they use an algorithm to redistribute the mass of these diagonal elements. They estimate the possibility of contagion by bankrupting each bank and counting how many other banks fail because of their exposure to the exogenously failed bank. A bank has no risk of contagion unless it owes more than its capital. One bank's failure, ${ }^{2}$ no matter how small, can trigger other more significant failures, the "domino effect".

\section{DATA AND METHODOLOGY}

Our main goal is to investigate the existence, and measure the dimension, of contagion in the interbank currency exchange market in Brazil. We follow the methodology of Upper and Worms (2002), but, instead of relying on estimates of the bilateral ex-

2 In this article, the term failure is used when a bank does not have a sufficient amount of liquid resources (government bonds) to cover its obligations on any given day. However, the bank may still possess other less liquid resources. 
posures, we work with the actual daily transactions of all Brazilian banks authorized to operate in the exchange market, between August $1^{\text {st }}, 2000$ and October 31 $1^{\text {st }}, 2002$. In this sense, we do not have to make assumptions about how to distribute the probability mass of the banks that are both lenders and borrowers. The database does not violate the Privacy Law of the Brazilian banking system, because even though the transactions are identifiable the banks involved are not.

The institutions in the market make many currency contracts on a reference day (D $+0)$. However, most of the contract's liquidation only happens in two days ( $\mathrm{D}+$ 2). If one of the banks breaks on $\mathrm{D}+0$ or $\mathrm{D}+1$, the Central Bank may cancel its contracts. If a transaction is canceled on $\mathrm{D}+0$ or $\mathrm{D}+1$ the only risk incurred by the participants still operating is the one associated with currency fluctuation. If the breakdown happens on $\mathrm{D}+2$, the contract is not cancelled and the participants incur both default risk and currency fluctuation risk.

When the currency contract is liquidated $(\mathrm{D}+2)$ the buyer of foreign currency is debited the value in \$Reais at 6 a.m., Brasilia time. In response, the seller of foreign currency authorizes the deposit of \$Dollars in the buyer's account abroad. However, because of time zone differences, these deposits are made in the afternoon, Brasilia time. If the buyer fails on $\mathrm{D}+2$, its assets are seized and administered by a third party. On the other hand, if the seller fails on $\mathrm{D}+2$ he would have received the domestic currency before making the transfer of the foreign currency. Because the transfers are not made simultaneously (payment versus payment - PVP) there is both a default risk and a currency fluctuation risk associated with these transactions.

If a transaction is made under the rules of the exchange Clearing House of the SPB, currency fluctuation is the only possible risk involved, since they use the payment versus payment protocol. Both parties have to deposit a guarantee of payment at the Clearing House and if one of them fails on the liquidation date, the other receives its own deposit plus the guarantee of the counterpart, valued in the currency of interest of the bank that does not go bankrupt, which may not value the same in foreign currency.

The loss of principal and the losses from currency fluctuations could cause a liquidity problem for the buyer. The solution would be a standby facility operation with the Central Bank. The buyer institution would receive a credit in its account and it would give to the Central Bank (repo operation) government public bonds of high liquidity for more than the market rate. If the referred bank (the buyer) does not own government bonds of high liquidity, the standby facility operation cannot be made, and it is not possible for the bank to obtain the foreign currency needed. In this case, the buyer could also go bankrupt, and it could cause the breakdown of a third institution in subsequent rounds. 
To model this situation, we generate a matrix $\mathbf{L}$ for each day of our sample, where $\mathrm{L}$ has dimension $\mathbf{n} \times \mathbf{n}$ and $\mathbf{n}$ is 114 (the number of banks authorized to operate in the exchange market). The elements in $\mathbf{L}$ represent all the transactions between the pairs of banks that are scheduled to be liquidated that day. Each element $\mathbf{a}_{\mathbf{i}, \mathrm{j}}$ of the matrix $\mathbf{L}$ represents the amount of foreign currency in \$Reais that bank $\mathbf{i}$ bought from bank $\mathbf{j}$ on that day. Therefore, the element $\mathbf{a}_{\mathbf{j}, \mathrm{i}}$ represents the value in $\$$ Reais of the foreign currency bank $\mathbf{j}$ bought from bank $\mathbf{i}$. We assume that $\forall i, j \in\{1, \cdots, 114\}, a_{i, j} \geq 0$ and that $\forall i, a_{i, i}=0$. The matrix $\mathbf{L}$ can be represented as follows:

$$
\mathbf{L}=\left[\begin{array}{cccccc}
0 & a_{1,2} & \cdots & a_{1, j} & \cdots & a_{1, n} \\
a_{2,1} & 0 & \cdots & a_{2, j} & \cdots & a_{2, n} \\
\vdots & \vdots & \ddots & \vdots & \ddots & \vdots \\
a_{i, 1} & a_{i, 2} & \cdots & a_{i, j} & \cdots & a_{i, n} \\
\vdots & \vdots & \ddots & \vdots & \ddots & \vdots \\
a_{n, 1} & a_{n, 2} & \cdots & a_{n, j} & \cdots & 0
\end{array}\right]
$$

Define $\mathbf{C}_{\mathbf{i}}$ as a row vector with the values of foreign currency purchased by bank $\mathbf{i}$ from all other banks $\mathbf{j}$ on a given day. The sum of all the elements of $\mathbf{C}_{\mathbf{i}}$, denoted by $\overline{\mathbf{C}}_{\mathbf{i}}$, represents the maximum loss for bank $\mathbf{i}$, if all the banks with which bank $\mathbf{i}$ negotiate go bankrupt on that day. Similarly, define $\mathbf{V}_{\mathbf{j}}$ as a column vector whose elements are the total value of foreign currency sold by bank $\mathbf{j}$ to all other banks $\mathbf{i}$ on a given day. The sum of all the elements of $\mathbf{V}_{\mathbf{j}}$, denoted by $\overline{\mathbf{V}}_{\mathbf{j}}$, represents the maximum loss that bank $\mathbf{j}$ can cause to the market if it goes bankrupt on that day.

If a bank is having difficulties honoring its contracts, it may have to liquidate part of its assets. However, not all assets have sufficient liquidity to avoid bankruptcy and the contagion effect. Government public bonds, bank reserves, stocks, and private bonds would have the desirable liquidity. However, the money from stock sales would only be available three days after the transaction day $(\mathrm{D}+3)$, making it useless to pay for currency contracts. A similar argument holds for private bond portfolios. ${ }^{3}$ The use of bank reserves would only postpone the liquidity problem for 15 days, given that this is the time period used when calculating compulsory reserve averages. In some cases the institution would have to propose a restructuring plan, as discussed in footnote 3 .

3 These portfolios could be taken to the Brazilian Central Bank as a guarantee for a loan to liquidate the referred currency contract. Moreover, a commercial bank would have to propose a restructuring plan to normalize its liquidity according to Resolution n.2.949 of the National Monetary Council, and Circular n.3.105 and Circular-Letter n. 3.009 of the Brazilian Central Bank.. 
Given that only government public bond portfolios ${ }^{4}$ have daily liquidity, we assume that only they are used to pay for currency exchange contracts if the bank does not have enough national or foreign currency to liquidate them. We collected daily data on the federal public bond portfolios held by all the Brazilian banks authorized to operate in the currency exchange market, between August 1 ${ }^{\text {st }}, 2000$ and October $31^{\text {st }}, 2002$.

Based on these portfolios we generate daily column vectors GPB (government public bonds) with dimension $\mathbf{n}$ by $\mathbf{1}$, where $\mathbf{n}$ is $\mathbf{1 1 4}$, the number of banks in the market. The vector elements represent the nominal value in \$Reais of the public bond portfolio of each bank. Initially, we exogenously fail ${ }^{5}$ each of the participant banks. When bank $\mathbf{i}$ is broken, all its transactions as a buyer remain unchanged, but it will not fulfill its obligations to pay the other banks as a seller of foreign currency. As a failed seller, bank i receives \$Reais but it does not send the \$Dollars. Therefore, bank $\mathbf{j}$ does not receive any money from bank $\mathbf{i}$ to liquidate its transactions and, therefore, $a_{j, i}=0, \forall j$.

In this case, $\mathbf{V}_{\mathbf{i}}$ would be a column vector of zeros and the $\mathbf{L}$ matrix would generate the following first round matrix Ll:

$$
\mathbf{L} \mathbf{1}=\left[\begin{array}{cccccccc}
0 & a_{1,2} & \cdots & 0 & \cdots & a_{1, j} & \cdots & a_{1, n} \\
a_{2,1} & 0 & \cdots & 0 & \cdots & a_{2, j} & \cdots & a_{2, n} \\
\vdots & \vdots & \ddots & \vdots & \ddots & \vdots & \ddots & \vdots \\
a_{i, 1} & a_{i, 2} & \cdots & 0 & \cdots & a_{i, j} & \cdots & a_{i, n} \\
\vdots & \vdots & \ddots & \vdots & \ddots & \vdots & \ddots & \vdots \\
a_{j, 1} & a_{j, 2} & \cdots & 0 & \cdots & 0 & \cdots & a_{j, n} \\
\vdots & \vdots & \ddots & \vdots & \ddots & \vdots & \ddots & \vdots \\
a_{n, 1} & a_{n, 2} & \cdots & 0 & \cdots & a_{n, j} & \cdots & 0
\end{array}\right]
$$

Based on $\mathbf{L l}$, we create an intermediary matrix $\mathbf{T}^{\mathbf{l}}$ associated with the first round to quantify the losses incurred by each of the institutions $\mathbf{j}$ on that day as a consequence of the exogenous failure of bank $\mathbf{i}$. We have $\mathbf{T}^{\mathbf{1}}=\mathbf{L}-\mathbf{L} \mathbf{1}$. An element $\mathbf{a}_{\mathbf{j}, \mathrm{i}}$ of matrix $\mathbf{T}^{\mathbf{l}}$

4 To collect data on the federal public bond portfolios of the studied banks, we take into account the value, in national currency (\$Reais), of those portfolios at the end of the day (values based on the unitary price). We only consider accounts with tradable bonds, and we ignore accounts associated with judicial processes, FAT, FGTS, and other blocked accounts.

5 We call an exogenous failure a default that is not generated by the currency exchange market. It could be that a big loss occurs in the derivative market, but the bank also has interbank currency operations and it is not able to liquidate them because of what happened in the other market. 
informs how much bank $\mathbf{i}$ will not pay bank $\mathbf{j} .{ }^{6}$ A second intermediary matrix, also associated with the first round, is $\overline{\overline{\mathbf{T}^{1}}}$ with dimension $\mathbf{n}$ by $\mathbf{1}$. It contains information on the values not received by each institution up to that moment as a consequence of the exogenously failed institution.

With matrices GPB and $\overline{\overline{\mathbf{T}^{1}}}$, we can determine how many banks breakdown in the first round because of the exposure to the exogenous failure of bank $\mathbf{i}$. We make use of a column vector $\mathbf{Q} 1=\mathbf{G P B}-\overline{\overline{\mathbf{T}^{1}}}$, where $\mathbf{Q 1} \mathbf{1}^{\prime}=\left(c_{1,1}, c_{2,1}, \ldots, c_{i, 1}, \ldots, c_{n, 1}\right)$. A bank $\mathbf{z}$ is considered bankrupt if $c_{z, 1}<0$, for $\mathrm{z} \neq \mathrm{i}$ (the exogenously failed bank). If this occurs we start second round calculations. In the second round we generate a matrix L2 based on $\mathbf{L} \mathbf{l}$ by setting the elements $\mathbf{a}_{\mathbf{j} \mathbf{z}}=0, \forall j$. We repeat the algorithm for the second round, creating a matrix $\mathbf{T}^{2}=\mathbf{L}-\mathbf{L} 2$, which determines the values not received by each institution $\mathbf{j}$ in the first two rounds.

In general, we build a matrix $\mathbf{L}(\mathbf{x})$, of dimension $\mathbf{n}$ by $\mathbf{n}$, with a number of zero columns equal to the number of banks bankrupt from round 1 to round $(x-1)$. A matrix $\mathbf{T}^{\mathbf{x}}=\mathbf{L}-\mathbf{L}(\mathbf{x})$ contains the values of the transactions not received from each broken bank from the $1^{\text {st }}$ to the $\mathrm{x}^{\text {th }}$ round. The sum of all non-received values by each institution is shown in $\overline{\overline{\mathbf{T}^{x}}}$. 7 The "bankrupt matrix" $\mathbf{Q}(\mathbf{x})=$ GPB $-\overline{\overline{\mathbf{T}^{x}}}$, indicates the number of bankrupt banks after the $\mathrm{x}^{\text {th }}$ round. If there exists an element of $\mathbf{Q}(\mathbf{x}), \mathfrak{c}_{\mathrm{j}, \mathrm{x}}$, such that $\mathbf{c}_{\mathfrak{j}, \mathrm{x}}<0$, for $\mathbf{j} \neq \mathbf{y}$ where $\mathbf{y}$ are the institutions that went bankrupt between rounds 1 and $(x-1)$, we should go on to round $(x+1)$.

With this design it is possible to count the number of institutions that may go bankrupt because of the exogenous failure of a given bank. We can also calculate the value of the non-liquidated operations up to a specific moment. This is how much the Central Bank would have to spend to avoid the propagation of bankruptcies (the contagion effect).

\section{RESULTS}

We exogenously fail an institution and we calculate all the rounds necessary for the contagion propagation to cease. We then count the number of bankrupt institutions excluding the initial breakdown (see Table 1). The procedure is repeated 114 times (number of banks operating in the market) for each of the 559 days between August $1^{\text {st }}, 2000$ and October $31^{\text {st }}, 2002$, excluding weekends and holidays.

6 The superscript indicates the round number that we are calculating.

7 The matrix $\overline{\overline{T^{x}}}$ represents the sum of how much each institution does not receive from all other institutions that fail before round $\mathrm{x}$, while matrix $V_{i}$ represents how much institution $i$ sells on a given day. 
Table 1 shows that in 490 out of 559 days only one or two banks go bankrupt as a consequence of the initial breakdown. However, for five days there were six bankruptcies and for two days seven institutions were contaminated by the exogenous breakdown. For most of the days between the second semester of 2001 and the first semester of 2002, just one bank went bankrupt because of an initial failure (Figure 3). During this period, there were only 14 days for which the number of bankruptcies generated was greater than 1 . The largest variations in the number of bankrupt institutions occurred during the second semesters of 2000 and 2002 (Figure 3).

TABLE 1 - FREQUENCIES OF MAXIMUM NUMBER OF BANKRUPT INSTITUTIONS BY DAY

\begin{tabular}{cc}
\hline Number of Bankruptcies & Number of Days \\
\hline 0 & 4 \\
1 & 312 \\
2 & 178 \\
3 & 35 \\
4 & 16 \\
5 & 7 \\
6 & 5 \\
7 & 2 \\
\hline
\end{tabular}

The increased variation in the second semester of 2002 is related to the uncertainty before the presidential elections, with a labor party candidate leading the polls. Many agents used foreign currency as a hedge against the risk of government default. Another important fact was the exchange rate passing the barrier of R \$/US\$ 3.00 which happened in the last week of July 2002 generating unbridled speculation.

FIGURE 3 - MAXIMUM AND AVERAGE NUMBER OF BANKRUPT INSTITUTIONS BY DAY

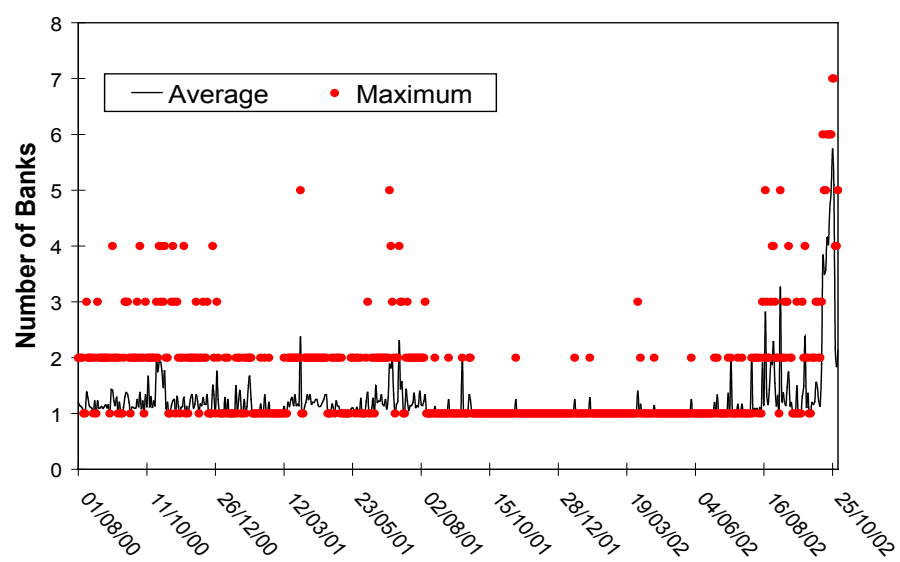


TABLE 2 - SOME CRITICAL DAYS IN THE PERIOD

\begin{tabular}{|c|c|c|c|c|c|c|c|}
\hline \multirow[t]{2}{*}{ Date } & \multicolumn{2}{|c|}{ Number of Banks } & \multicolumn{2}{|c|}{$\begin{array}{c}\text { Values } \\
\text { (R\$ millions) }\end{array}$} & \multicolumn{2}{|c|}{$\begin{array}{c}\text { Values } \\
\text { (US\$ millions) }\end{array}$} & \multirow{2}{*}{$\begin{array}{c}\text { Gross Volume } \\
\text { (US\$ billions) } \\
\text { Total }\end{array}$} \\
\hline & Average & Maximum & Average & Maximum & Average & Maximum & \\
\hline $05 / 09 / 2000$ & 1,42 & 4 & 114,42 & $1.210,69$ & 62,57 & 662,09 & 4.78 \\
\hline $28 / 03 / 2001$ & 2,37 & 5 & 26,21 & 138,40 & 12,39 & 65,40 & 3.44 \\
\hline 02/07/2001 & 1,88 & 5 & 28,13 & 197,78 & 12,10 & 85,10 & 1.98 \\
\hline $12 / 07 / 2001$ & 1,45 & 3 & 31,20 & 260,25 & 12,28 & 102,40 & 2.21 \\
\hline 01/07/2002 & 1,00 & 1 & 191,90 & 949,09 & 67,13 & 332,00 & 1.80 \\
\hline $13 / 08 / 2002$ & 1,11 & 2 & 114,08 & 879,16 & 35,56 & 274,00 & 1.08 \\
\hline $19 / 08 / 2002$ & 2,82 & 5 & 223,93 & 287,99 & 71,92 & 92,50 & 0.61 \\
\hline $26 / 09 / 2002$ & 1,50 & 2 & 96,40 & 503,42 & 25,70 & 134,22 & 0.94 \\
\hline $25 / 10 / 2002$ & 5,74 & 7 & 172,41 & 315,46 & 45,36 & 83,00 & 1.07 \\
\hline $28 / 10 / 2002$ & 5,10 & 7 & 205,42 & 326,48 & 54,93 & 87,30 & 1.30 \\
\hline
\end{tabular}

Note: The maximums are in boldface.

One would expect that after the implantation of the Brazilian System of Payment (SPB), on April 22, 2002, there would be a reduction in the recursive breakdowns. Even though the agents are not obliged to operate inside the Clearing House, during August 2002 more than half of the transactions were made in this environment. Despite this, the highest average number of bankruptcies happened during October 2002. On the Friday just before the presidential elections (Sunday, October $27^{\text {th }}$ 2002) an average of 5.74 and a maximum of 7 institutions went bankrupt, besides the exogenous failure. On the Monday just after the presidential elections, the maximum number of bankruptcies was also 7 , but the average fell to 5.1 institutions. The average of the maximum number of breakdowns was a little above 5.5 for the second half of October 2002.

\section{FIGURE 4 - AVERAGE NUMBER OF BANKRUPT BANKS AND MAXIMUM NON-PAID VALUES IN THE PERIOD}

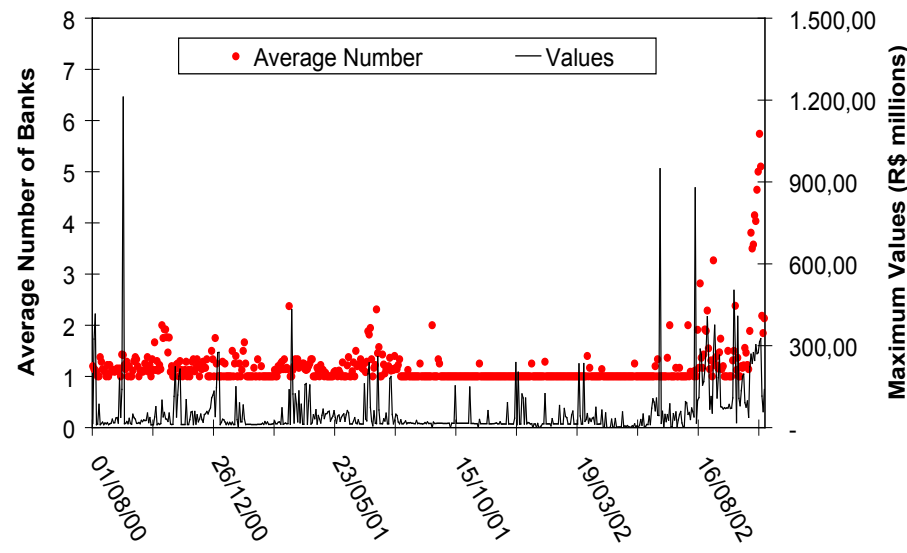


The failure of an institution generates contagion in the system and hence some operations are not liquidated. This leads us to the dilemma of the Central Bank, which has to choose between canceling the non-liquidated operations (this may cause systemic risk) and liquidating the operations with its own resources. The second choice may lead to a moral hazard problem. If the Central Bank had decided to liquidate the operations with its own resources in our setup, the maximum loss incurred would be around R\$1.21 billion (corresponding to US\$662 million) on September $5^{\text {th }}, 2000$ (Table 2), representing $14 \%$ of the total amount of transactions in the exchange market on that day. ${ }^{8}$ On October $25^{\text {th }}$ and October $28^{\text {th }}$ of 2002 (the day before and after the presidential elections) these losses would be R $\$ 315$ million (US\$83 million) and R\$326 million (US\$87.3 million) respectively. Two other peaks of maximum losses occurred on July $1^{\text {st }}, 2002$ (R\$ 949 million; US\$ 332 million) and on August 13 ${ }^{\text {th }}$, 2002 (R\$ 879 million; US\$ 274 million). The second date was the start of a period of intensified speculation about the presidential elections (the pattern is similar in both \$Reais and in \$Dollars). Figure 4 and Table 2 illustrate these results.

\section{CONCLUSION}

We have shown that the Brazilian interbank currency market can generate great losses to the banking system with the exogenous failure of an institution. We observe that the largest number of institutions were affected by contagion around the presidential elections. There seems to exist a high correlation between the political moment and currency contagion, a fact that will be explored in future work.

The largest number of bankrupt institutions by contagion occurred after the implantation of the Brazilian System of Payment (SPB), when only 40\% of the operations were realized outside the Currency Clearing House. If the SPB had not been implemented the results may have been worse.

It is important to point out that Circular n. 3.105 of the Central Bank of Brazil authorizes the banks to use public bonds that are allocated in repurchase agreement operations in order to increase market liquidity. Without this mechanism, contagion would be a substantial problem, as shown by our simulations.

Given that the breakdown of an institution at the most critical time of the analysis (October 2002) could bring seven other institutions to bankruptcy, and that the maximum amount of resources necessary to abort a contagion was above R $\$ 1.2$ billion on September 5,2000 , it is important to create a mechanism to reduce the possible

8 The total gross volume of transactions in the exchange market on September $5^{\text {th }}$ of 2000 was US\$ 4.78 billions. 
number of bankruptcies and losses. The Brazilian Central Bank should create incentives to induce banks to perform all their operations within the Currency Clearing House. This solution could be, in principle, more expensive for the institutions, but there would be a better monitoring of the agents by the principals and a better control of risk. A possible way of doing this would be requiring an increased portfolio of government public bonds for the institutions that operate outside of the Clearing House. This could make the banks decide to use the Clearing House for all its operations.

Similar calculations of contagion, using all the transactions in the market and all the Clearing Houses, would be an important future work in this area.

\section{REFERENCES}

Allen, F; Gale, D. Financial contagion. Journal of Political Economy, v. 108, n. I, p. $1-33,2000$.

Diamond, D. W.; Dybvig, P. H. Bank runs, deposit insurance, and liquidity. Journal of Political Economy, v. 91, p. 401-19, June 1983.

Flannery, M. Financial crises, payment system problems, and discount window lending. Journal of Money, Credit and Banking, v. 28, n. 4, p. 804-824, 1996.

Furfine, C. H. Interbank exposures: quantifying the risk of contagion. Bank for International Settlements - Working Paper n. 70, 1999.

Huang, H.; Xu, C. Financial institutions, financial contagion and financial crises. IMF Working Paper, n. 00/92, 2000.

Jacklin, Charles J.; Bhattacharya, Sudipto. Distinguishing panics and informationbased bank runs: welfare and policy implications. Journal of Political Economy, v. 96, p. $568-92,1988$.

Peñaloza, Rodrigo. On shadow-prices of banks in real-time gross settlement systems. 2002. $\mathrm{PhD}$ Dissertation, University of California, Los Angeles - UCLA.

Rochet, J-C.; Tirole, J. Interbank lending and systemic risk. Journal of Money, Credit and Banking, v. 28, n. 4, p. 733-762, 1996.

Sheldon, G.; Maurer, M. Interbank lending and systemic risk: an empirical analysis for Switzerland. Swiss Journal of Economics and Statistics, v. 134, n. 4.2, p. 685704, 1998.

Upper, C.; Worms, A. Estimating bilateral exposures in the German interbank market: is there a danger of contagion? Discussion Paper (09/02) - Deutsche Bundesbank, 2002. 